\title{
Anti-Diarrheal Activity of the Aqueous Leaf Extract of Ageratum Conyzoides in Wistar Rats
}

\author{
${ }^{* 1}$ EMUDAINOHWO, JO. T., ${ }^{1}$ ERHIRHIE, EO; ${ }^{1}$ MOKE, EG \\ Department of Pharmacology and Therapeutics Delta State University, Abraka, Nigeria \\ Emudainohwo, j.o.t. (jot.emudainohwo@yahoo.com) \\ Erhirhie,e.o.(erhirhieochuko@yahoo.com) \\ Moke,e.g. (hiligoodies@gmail.com)
}

\begin{abstract}
The leaves of Ageratum conyzoides had been reportedly used in traditional medicine in the treatment of diarrhea. Thus its aqueous leaf extract was investigated for its possible anti-diarrheal property using castor oil induced diarrheal, charcoal meal intestinal transit and castor oil-induced enteropooling models in Wistar rats to substantiate its folklore claim. In castor oil induced diarrheal model, $500 \mathrm{mg} / \mathrm{kg}$ and 1000 $\mathrm{mg} / \mathrm{kg}$ body weight doses of the extract showed dose dependent remarkable anti-diarrheal activity evidenced by delay in diarrheal latency, reduction in the rate of defecation and consistency, although it was not comparable to that loperamide which elicited absent of diarrheal. In charcoal meal intestinal transit models, extract doses $(500 \mathrm{mg} / \mathrm{kg}$ and 1000 $m g / k g$ ) also elicited dose dependent anti-diarrheal activity, evidenced by reduction in distance travelled by charcoal meal. Although, it was not also comparable to that of intraperitoneal injection of standard drug, Atropine sulphate at a dose of $0.1 \mathrm{mg} / \mathrm{kg}$ body weight. Experimental findings showed that aqueous leaf extract of Ageratum conyzoides possess anti-diarrheal activity and may be a potential source of anti-diarrheal drug in future. Higher doses may possess better anti-diarrhoeal properties. (C) JASEM
\end{abstract}

\section{http://dx.doi.org/10.4314/jasem.v19i2.1}

KEY WORDS: Ageratum conyzoides, anti-diarrheal activity, loperamide, castor oil, atropine sulphate. activated charcoal, enteropooling, Wistar rats.

\section{Introduction}

An estimated 1.7 billion cases of diarrheal occurs every year, with about 760,000 children of 5 years and below in many developing countries, dying from the disease (WHO, 2013). Diarrheal is characterized by an increase in the frequency, fluidity and volume of feaces, much more than the normal for an individual (WHO, 2013). Diarrheal has been shown to be due to an imbalance between the secretory and absorptive processes in the intestines (Field, et al., 1989) giving rise to increased frequency of bowel movements, watery stools and abdominal pain. The consequences of diarrheal are stark dehydration, bodily fluid and electrolyte loss (Carlos and Saniel, 1990).

With many of the available synthetic anti-diarrheal drugs associated with many unwanted side effects (Rajeev, et al., 2010; Limberd, 1999), the search for safe and effective anti-diarrheal agents continues. In this quest, quite a lot of medicinal plants have been researched for potential anti-diarrheal properties (Agbon et al., 2013; WHO, 2002; Victoria, et al., 2000).
Ageratum conyzoides L., belonging to the family Asteraceae is an annual plant quite popular amongst traditional medicinal practitioners in places such as Central and South America, Caribbean, Australia, South China, South-east Asia, India and Nigeria, (Okunade, 2002). The phytochemical analysis of the extract and fractions of Ageratum conyzoides by Ukwe and colleagues (2010) showed the presence of reducing sugars, saponins, carbohydrates, alkaloids, glycoside, proteins, flavonoids, tannins, fats and oil. Okunade, (2002) had previously reported the presence of sesquiterpenes, triterpenoids, chromones, benzofurans and chromenes in Ageratum conyzoides.

Traditionally, the leaves or whole plant have reportedly been used by local folks for fever, pneumonia, cold, rheumatism, spasm, headache and curing wounds (Ming, 1999) and also for the treatment of colic and rheumatism (Marques, et al. 1988; Oliveira, et al. 1993). The leaves have also been employed as insecticide (Ramachandran and Nair, 1981); as an antidote for treating snake bites (Jain and Sahu, 1993); as anti-tetanus agent (Siddiqui 
and Husain, 1992); and also for treating skin diseases (Sankaran and Alagesaboopathi, 1995) and ringworm infections (Anuradha, et al., 1986)

Past studies on Ageratum conyzoides have been able to show that it has Antimalarial activity (Ukwe et al., 2010); Antibacterial and wound healing properties (Akinyemi, et al., 2005; Oladejo, et al., 2003). While Silva et al. (2010) and Kong et al. (2005) demonstrated the spasmolytic and gastro-protective activities of the plant. Moura, et al. (2005) equally demonstrated the anti-inflammatory actions of the plant. Rosangkima and Prasad (2004) have also shown that Ageratum conyzoides possesses antitumour activity, just as the analgesic properties have been revealed by Sampson et al. (2000).

With no research information on the anti-diarrheal activity of Ageratum conyzoides, this study sets out to investigate the folklore believe of anti-diarrheal properties associated with Ageratum conyzoides in experimental induced diarrheal model in Wistar rats.

\section{MATERIALS AND METHODS}

Plant collection and identification: Fresh leaves of Ageratum conyzoides was collected in the month of August, 2014, from the bush along Business Centre Road, Abraka, Nigeria. The leaves were identified and authenticated as Ageratum conyzoides by the Taxonomist at the Department of Pharmacognosy, Faculty of Pharmacy, Delta State University, Abraka, Nigeria.

Preparation of extract: The leaves of Ageratum conyzoides were washed and air dried for a period of ten (10) days. They were later ovum dried at a temperature of $40^{\circ} \mathrm{C}$ and were blended into powder using electrical blender. Two hundred and fifty gram $(250 \mathrm{~g})$ of the powered leaf was soaked in $1000 \mathrm{ml}$ of distilled water (corresponding to $25 \mathrm{~g}-100 \mathrm{ml}$ ) for 72 hours to enable proper maceration. This was later filtered with a Whatman's No 1 filter paper, and was concentrated under pressure in a rotary extraction apparatus. Final viscous filtrate recovered was further concentrated in the oven at $40^{\circ} \mathrm{C}$ to produce 45 gram of a past-like extract (percentage yield was 18\%) which was stored in air-tight sample bottle and refrigerated before use.

Animal: A total of one hundred and twenty (120) Wistar rats of both sex, and weighing between 150 200 grams were procured from the breeding colony of the Animal House of the Faculty of Basic Medical Sciences, Delta State University, Abraka, Nigeria for the purpose of the study. The animals were acclimatized for 14 days and were maintained under standard laboratory condition (i.e. at room temperature of $24 \pm 2{ }^{\circ} \mathrm{C}$ in an approximate 12 hour light/dark cycle). The animals were fed with standard rodent pellet diet (Savannah Feeds, Nigeria) and provided with drinking water ad libitum. The animals received humane care in line with the NIH guidelines for the care and use of laboratory animals as approved by the Ethical Committee of the Faculty of Basic Medical Sciences, Delta State University, Abraka, Nigeria.

Chemicals and Reagents: Atropine sulphate (Vulcan Laboratories Ltd), and Loperamide (Zim Laboratories Ltd, Nagpur, India, Batch no: E406), castor oil (Bell, Sons and Co, Southport, England, Batch no: 8560P1), Distilled water (served as the vehicle), from the main laboratory, Department of Pharmacology and Therapeutics, Delta State University, Abraka, Nigeria), charcoal meal (From Kunimed Pharmaceuticals Ltd) were used.

Experimental design: The animals were weighed and their weight noted before they were randomly divided into three (3) groups of forty (40) animals each for experiments on castor oil-induced diarrhoeal; gastrointestinal motility; and castor oil - induced enteropooling. Each group of forty (40) animals was further randomized into four (4) groups of ten (10) animals each.

Effect of aqueous leave extract of Ageratum conyzoides on castor oil-induced diarrheal.: Forty (40) rats were fasted for 18 hours and were randomly allotted to 4 groups of 10 rats each (Groups $1-4$ ). Castor oil was administered to all the animals in the groups at a dose of $1 \mathrm{ml} /$ animal orally for the induction of diarrheal (Doherty, 1981). Thirty minutes before castor oil administration, the animals in Group 1 (Negative control) received vehicle (Distilled water, $10 \mathrm{ml} / \mathrm{kg}$ ), while the animals in Group 2 (Positive control) received the reference/standard drug - loperamide $(2 \mathrm{mg} / \mathrm{kg}$ body weight). Animals in Groups 3 and 4 received leave extracts of Ageratum conyzoides at doses of 500 and $1000 \mathrm{mg} / \mathrm{kg}$ body weight respectively by oral route.

Animals of all groups were placed separately in individual cages, with absorbent papers placed under the perforated cages. Total number of feaces, total number of diarrheal feaces passed and the total weight of the feaces were observed and recorded within a time frame of 4 hour (Izzo et al., 1994). The findings in groups $2-4$ were compared with that of group 1 (the negative control). The onset of diarrhea (diarrheal latency) was measured as the time interval (in minutes) between the time of administration of castor oil and the appearance of the first diarrheic 
stool. The faecal matter was collected and weighed after the entire observation period recorded in hours.

Effect of aqueous leave extract of Ageratum conyzoides on gastrointestinal motility: A second group of forty (40) rats were fasted for 18 hours and were randomly allotted to 4 groups of 10 rats each (Group 1 - 4). Charcoal meal was used as a diet marker. Animals in Group 1 (Negative control) received vehicle (Distilled water, $10 \mathrm{ml} / \mathrm{kg}$ ), while the animals in Group 2 (Positive control) received the reference/standard drug - atropine sulphate (0.1 $\mathrm{mg} / \mathrm{kg}$ intraperitoneal) (Owolabi, et al., 2007). Animals in Groups 3 and 4 received leave extracts of Ageratum conyzoides constituted in distilled water $(10 \mathrm{ml} / \mathrm{kg})$, at doses of 500 and $1000 \mathrm{mg} / \mathrm{kg}$ body weight respectively by oral route.

Thirty minutes later each animal was given $1 \mathrm{ml}$ of charcoal meal (10\% activated charcoal in distilled water) orally. Thirty minutes after the administration of charcoal meal, each animal was sacrificed under chloroform anesthesia and a laparotomy was carried out to reveal the small intestine which was isolated. The distance covered by the charcoal meal in the intestine was measured from the pylorus to the caecum and expressed as a percentage relative to control group. (Boominathan et al., 2005; Mascola et al., 1994; Chidume et al., 2001).

Effect of aqueous and ethanol bark extract of Ageratum conyzoides on castor oil-induced enteropooling: A third group of forty (40) rats were fasted for 18 hours and were randomly allotted into 4 groups of 10 rats each (Group $1-4$ ). Animals in Group 1 (Negative control) received vehicle (Distilled water, $10 \mathrm{ml} / \mathrm{kg}$ ), while the animals in Group 2 (Positive control) received the reference/standard drug - atropine sulphate (0.1 $\mathrm{mg} / \mathrm{kg}$ intraperitoneally) (Owolabi, et al., 2007). Animals in Groups 3 and 4 received leave extracts of Ageratum conyzoides constituted in distilled water $(10 \mathrm{ml} / \mathrm{kg})$, at doses of 500 and $1000 \mathrm{mg} / \mathrm{kg}$ body weight respectively by oral route.

One hour after treatment, each rat was given $1 \mathrm{ml}$ castor oil by oral gavage. Two hours after administration of castor oil, animal were sacrificed under chloroform anesthesia and a laparotomy was carried out to reveal the small intestine which was tied at the pyloric and ceacal junction and the content of each intestine was squeezed into a graduated test tube, and its content was measured (Robert et al., 1976).

Data Analysis: Results of the study were expressed as mean \pm Standard Deviation of ten replicates, $n=10$. Raw data were subjected to statistical analyses by one way analyses of variance (ANOVA), followed by post-hoc Turkey's test, using statistical package for social science (SPSS) version 16 for windows. Statistical significance was established when $\mathrm{P}<0.05$.

\section{RESULTS AND DISSCUSION}

Table 1: Effects of Ageratum conyzoides aqueous leaf extract on charcoal meal test in Wistar rats.

\begin{tabular}{llll}
\hline & $\begin{array}{c}\text { Length of small } \\
\text { intestine }(\mathrm{cm})\end{array}$ & $\begin{array}{l}\text { Distance travelled } \\
\text { by charcoal meal }(\mathrm{cm})\end{array}$ & $\begin{array}{l}\text { Percentage inhibition } \\
(\%)\end{array}$ \\
\hline Group 1 (Control) & $113.6 \pm 3.94$ & $24.84 \pm 2.22$ & \\
Group 2 (Atropine, $0.1 \mathrm{mg} / \mathrm{kg})$ & $113.4 \pm 1.71$ & $11.32 \pm 3.21^{*}$ & $54.43 \%$ \\
Group 3 (Extract, $500 \mathrm{mg} / \mathrm{kg})$ & $110.7 \pm 2.02$ & $23.50 \pm 7.07^{\mathrm{a}}$ & $5.39 \%$ \\
Group 4 (Extract, $1000 \mathrm{mg} / \mathrm{kg})$ & $106.6 \pm 2.48$ & $19.74 \pm 7.26^{\mathrm{a}}$ & $20.53 \%$ \\
\hline
\end{tabular}

Values are expressed as mean \pm standard Deviation, $\mathrm{n}=10 . * \mathrm{P}<0.05$ : Significantly

different from group $1 .{ }^{\mathrm{a}} \mathrm{P}<0.05$ : Significantly different from group 2 .

Effect of Ageratum conyzoides aqueous leaf on charcoal meal test: From table 1 above, Atropines significantly $(\mathrm{P}<0.05)$ reduced distance travelled by charcoal meal $(11.32 \pm 3.21)$ when compared to control (24.84 \pm 2.22$)$, low dose and high dose (23.50 \pm 7.07 and $19.74 \pm 7.26)$ respectively. Percentage inhibition was highest in group Atropine (54.43\%) while the extract caused dose dependent inhibition in distance travelled. 
Table 2: Effects of Ageratum conyzoides on castor oil induced diarrheal in Wistar rats.

\begin{tabular}{llllll}
\hline & $\begin{array}{l}\text { Diarrhoeal latency } \\
\text { (Mins) }\end{array}$ & $\begin{array}{l}\text { Number of diarrheal } \\
\text { feaces }\end{array}$ & $\begin{array}{l}\text { Total number } \\
\text { of feaces }\end{array}$ & $\begin{array}{l}\text { Total weight of } \\
\text { feaces (g) }\end{array}$ & $\begin{array}{l}\text { Percentage inhibition } \\
\text { of diarrheal feaces }(\%)\end{array}$ \\
\hline Group 1 (Control) & $47.8 \pm 13.6$ & $9.2 \pm 2.28$ & $11.2 \pm 4.38$ & $2.27 \pm 0.4$ & $0 \%$ \\
& Nil & Nil & Nil & Nil & $100 \%$ \\
$\begin{array}{l}\text { Group 2 } \\
\text { (Loperamide, 2 }\end{array}$ & & & & \\
mg/kg) & & $7.0 \pm 1.22^{*}$ & $0.98 \pm 0.5^{*}$ & $56.52 \%$ \\
$\begin{array}{l}\text { Group 3 (Extract, } \\
500 \mathrm{mg} / \mathrm{kg})\end{array}$ & $163.2 \pm 70.5^{*}$ & $4.0 \pm 0.71^{*}$ & & & \\
$\begin{array}{l}\text { Group 4 (Extract, } \\
1000 \mathrm{mg} / \mathrm{kg})\end{array}$ & $194.4 \pm 31.0^{*}$ & $3.8 \pm 1.48^{*}$ & $6.0 \pm 1.87 *$ & $0.51 \pm 0.1^{*}$ & $58.69 \%$
\end{tabular}

Values are expressed as mean \pm standard deviation, $\mathrm{n}=10 . * \mathrm{P}<0.05$ : Significant when compared with group 1 .

Effect of Ageratum conyzoides aqueous leaf extract on castor oil induced diarrheal: From table 2 above the extract $(500 \mathrm{mg} / \mathrm{kg}$ and $1000 \mathrm{mg} / \mathrm{kg}$ ) caused dose dependent significant $(\mathrm{P}<0.05)$ increase in diarrheal latency when compared with control group. However, no diarrheal was observed in loperamide treated group. $500 \mathrm{mg} / \mathrm{kg}$ and $1000 \mathrm{mg} / \mathrm{kg}$ caused a significant decrease $(\mathrm{P}<0.05)$ in number of diarrheal feaces, total number of feaces, and total weight of feaces when compared to control group. Percentage protection level was highest in loperamide treated group $(100 \%)$ followed by high dose $(58.69 \%)$ and least in the low dose of extract $(56.52 \%)$.

Table 3: Effects of Ageratum conyzoides on castor oil induced enteropooling in Wistar rats.

\begin{tabular}{llll}
\hline & $\begin{array}{l}\text { Weight of intestine } \\
(\mathrm{g})\end{array}$ & $\begin{array}{l}\text { Volume of in } \\
\text { testinal content }(\mathrm{ml})\end{array}$ & $\begin{array}{l}\text { Percentage inhibition in } \\
\text { intestinal volume }(\%)\end{array}$ \\
\hline Group 1: Control & $5.34 \pm 0.54$ & $3.54 \pm 0.22$ & \\
Group 2 (Loperamide, $2 \mathrm{mg} / \mathrm{kg})$ & $3.26 \pm 0.17^{*}$ & $1.22 \pm 0.27^{*}$ & $65.54 \%$ \\
Group 3 (Extract, $500 \mathrm{mg} / \mathrm{kg})$ & $4.26 \pm 0.19^{* \mathrm{a}}$ & $2.48 \pm 0.13^{* \mathrm{a}}$ & $29.94 \%$ \\
Group 4 (Extract, $1000 \mathrm{mg} / \mathrm{kg})$ & $3.82 \pm 0.25^{*}$ & $2.22 \pm 0.36^{* \mathrm{a}}$ & $37.29 \%$ \\
\hline
\end{tabular}

Values are expressed as mean \pm standard deviation, $\mathrm{n}=10$. $* \mathrm{P}<0.05$ : Significantly different from group $1 .{ }^{\mathrm{a}} \mathrm{P}<0.05$ : Significantly different from group 2 .

Effect of Ageratum conyzoides aqueous leaf extract on castor oil induced diarrheal: From table 3 above administration of loperamide and extract $(500 \mathrm{mg} / \mathrm{kg}$ and $1000 \mathrm{mg} / \mathrm{kg}$ ) caused dose dependent significant reduction in weight of intestine when compared to control group. Loperamide reduced intestinal volume by $65.54 \%$ followed by $37.29 \%$ in low dose and $29.94 \%$ high dose respectively.

The present study was carried out to investigate the anti-diarrheal potential of the aqueous leaf extract of Ageratum conyzoides in Wistar rats using castor oil induced diarrhea, charcoal meal intestinal transit and castor oil induced enteropooling models.

Agents with anti-diarrheal properties had been shown to decrease intestinal motility and distance travelled by charcoal meal due to increase reabsorption of water (Anup, et al., 2007; Rajabhau, et al., 2011). From results of the study (table 1), there was significant decrease $(\mathrm{P}<0.05)$ in distance travelled by charcoal meal $(54.43 \%)$ following the administration of Atropine $(0.1 \mathrm{mg} / \mathrm{kg})$, an already established antidiarrheal agent (Anup, et al, 2007).
Dose dependent decrease in distance travelled by charcoal meal $(5.39 \%$ and $20.53 \%$ respectively) following treatment with extract at $500 \mathrm{mg} / \mathrm{kg}$ and $1000 \mathrm{mg} / \mathrm{kg}$ (table 1), suggests the anti-motility potential of Ageratum conyzoides. Although, it was not comparable to that of Atropine. In line with other studies, 200 and $100 \mathrm{mg} / \mathrm{kg}$ of Costus lucanusianus reduced distance travelled by charcoal meal in mice (Owolabi, et al., 2007). Psidium guajava extract (50, 100,200 and $400 \mathrm{mg} / \mathrm{kg}$, p.o.) also dose-dependently and significantly $(\mathrm{P}<0.05-0.01)$ decreased the propulsive movement and transit of charcoal meal through the gastrointestinal tract. Atropine sulphate (1 $\mathrm{mg} / \mathrm{kg}$, p.o.) produced greater anti-motility effect than the highest dose of Psidium guajava extract (400 $\mathrm{mg} / \mathrm{kg}$, p.o.) (John et al., 2008).

Castor oil, known to induce diarrhea after administration to experimental animals, usually results in the release of ricinoleic acid and this usually causes a change in the integrity of the fluid and electrolyte balance in the mucosa of the gastrointestinal tract (Ammon, et al., 1976). From table 2, administration of castor oil to Wistar rats facilitated the onset of diarrheal, increased the 
frequency of defecation, decreased the weight of wet stools, and increased the frequency of diarrheal stool.

Agents demonstrating anti-diarrheal properties had been evaluated by their ability to delay diarrheal latency, decrease, weight of diarrheal feces as well as well as decrease number of feces (Atiqur et al, 2011; Pazhani, et al., 2001). From results of Castor oil induced diarrhea, diarrheal was not found throughout the period of observation in Loperamide group, indicating that loperamide elicited protection against diarrheal features associated with castor oil. Also, loperamide reduced intestinal volume by $65.54 \%$ followed by $37.29 \%$ in low dose and $29.94 \%$ high dose respectively in castor oil induced enteropooling model (Table 3). Loperamide had been shown to decrease stool frequency and also increase the consistency of the stools and it is effective in the treatment of short-term or chronic diarrhea (Atiqur, et al., 2011). Treatment with 500 and $1000 \mathrm{mg} / \mathrm{kg}$ extract caused dose dependent delay in diarrheal latency, decrease in number of feces and weight of feces (table 2). These features demonstrated by the extract suggest its anti-diarrheal potential; however its effect was not comparable to that of Loperamide. Previous studies had shown that Psidium guajava leaf aqueous extract (50,100, 200 and $400 \mathrm{mg} / \mathrm{kg}$, p.o.) dose dependently and significantly delayed the onset of diarrheal, reduced the frequency of defaecation and the wetness of the faecal droppings (reduction in the number of wet stools and total stools), and decreased the weight of wet stools and the general diarrhea score, including the hard, mild and copious stools (John, et al, 2008). Costus lucanusianus at doses of $100 \mathrm{mg} / \mathrm{kg}, 200 \mathrm{mg} / \mathrm{kg}$ and $400 \mathrm{mg} / \mathrm{kg}$ also caused a marked inhibition of diarrheal response following castor oil administration (Owolabi, et al., 2007).

The anti-diarrheal properties of aqueous leaf extract of Ageratum conyzoides could be attributed to its phyto constituents such as; reducing sugars, saponins, carbohydrates, alkaloids, glycoside, proteins, flavonoids, tannins, fats and oil, as earlier reported by Rajabhau, et al., (2011) and Okunade, (2002).

Plants possessing alkaloids, flavonoids, saponins, steroids, and tannins, had been reported to elicit antidiarrheal activity by acting on the gastrointestinal tract, having antispasmodic (Lima, et al., 2005) and anti-secretory properties (Atta and Moneir, 2004; Carlo, et al., 1994). Flavonoids have an ability to inhibit intestinal motility and hydroelectrolytic secretions while tannins precipitate proteins, reducing secretion and peristaltic movements (Venkatesan, et al., 2005; Rajeev, et al., 2010; Oliver, 1960). Ezekwesili, et al., (2010) had also reported the presence of anthocyanins, essential oils, phenols, triterpenes, quercetin and vitamin C, Quercetin as the main active constituent responsible for the spasmolytic and anti-diarrheal effects of the leaf extract of psidium guajava.

On the basis of this present finding, the aqueous leaf extract of Ageratum conyzoides may have elicited related mechanisms due to the phytoconstituents.

Conclusion: Scientifically established proofs of acclaimed efficacies of herbal medicine give credence to orthodox medications. On the basis of results of these investigations, the use of Ageratum conyzoides in the treatment of diarrheal is substantiated from its antispasmodic activities evidenced by delay in diarrheal latency, decrease in number of feces and decrease in weight of feces makes it good candidate for further works in diarrheal management. It is therefore recommended that further in vivo studies on the fractions and in vitro studies on the isolated compounds of Ageratum conyzoides is necessary to establish the possible mechanism of action for its antidiarrhea activity.

\section{REFERENCES}

Akah, PA. (1988). Haemostatic Activity of Aqueous Leaf Extract of Ageratum conyzoides L. Pharmaceutical Biology, Vol. 26, No. 2: Pages 97-101.

Akinyemi, KO., Oladapo, O., Okwara, CE., Ibe, CC. and Fasure, KA. (2005) Screening of crude extracts of six medicinal plants used in SouthWest Nigerian unorthodox medicine for antimethicillin resistant Staphylococcus aureus activity BMC Complement Altern Med. 5: 6.

Atta, AH and Mouneir, SM. (2004). Antidiarrhoeal activity of some Egyptian medicinal plant extracts. J. Ethnopharmacol. 92: 303-309.

Boominathan, R., Devi, BP., Dewanjee, S. and Mandal, SC. (2005). Studies on antidiarrhoeal activity of Ionodium suffruticosam ging. (violaceae) extract in rats. Recent Progress in Medicinal Plants (Phytotherapeutics). 10: 375-380.

Carlo, DC., Mascolo, N,. Izzo ,.AA, and Capasso, F. (1994). Effects of quercetin on the gastrointestinal tract in rats and mice. Phytol. therapy Res. 8: 42-45.

Doherty, SS. (1981). Inhibition of arachinodic acid release, mechanism by which glucocorticoids 
inhibit endotoxin-induced diarrhoea. British J.Pharmacol; 73: 549-554.

Durodola, J.J. (1977). Antibacterial property of crude extracts from herbal wound healing remedyAgeratum conyzoides. Planta Med. 32:388-390.

Ezekwesili, J.O., Nkemdilim, U.U and Okeke, C.U. (2010). Mechanism of antidiarrhoeal effect of ethanolic extract of Psidium guajava leaves. Biokemistri. Vol. 22, No. 2. Pg 85-90.

Field, M., Rao, M.C. and Chang, E.B. (1989). Intestinal electrolyte transport and diarrhoea disease. New England J. Med. 321: 800-806.

Fontaine, O. (1988). Bacterial diarrhoea and treatment. Lancet. 331: 1234-1235.

Hardman, JG. And Limberd LE. (1992). The Pharmacological basis of therapeutics. In: Goodman and Gilman's (Eds), 10th edition, MacGraw Hill, New York, pp. 914- 931.

Igoli, JO., Ogaji. OG., Tor-Anyiin, TA. and Igoli, NP. (2005).Traditional medicine practice amongst the Igede people of Nigeria (Part II). Afr. J. Trad. Comp. Alt. Med., 2: 134-152.

John, A.O. Ojewole, Emmanuel, O. Awe and Witness D.H. Chiwororo. (2008). Antidiarrhoeal activity of Psidium guajava Linn. (Myrtaceae) leaf aqueous extract in rodents. J. Smooth Muscle Res. 44 (6): 195-207.

Kong, H., Hu, F., Xu, X., Zhang, M. and Liang, W. (2005) Volatile allochemicals in the Ageratum conyzoides intercropped citrus orchard and their effects on mites Amblyseius newsami and Panonychus citri. J Chem Ecol. 31.(9): 2193-203.

Lima, JT, Almeida, JR., Barbosa-Filho, JM., Assis, TS., Silva, MS. and Dacunha, EV. (2005). Spasmolytic action of diplotropin, a furanoflavan from Diplotropis ferruginea Benth., involves calcium blockade in ginea-pig ileum. Naturforsch; 60:1-8.

Lin Chau Ming, (1999). Ageratum conyzoides: A Tropical Source of Medicinal and Agricultural Products. Reprinted from: Perspectives on new crops and new uses. J. Janick (ed.), ASHS Press, Alexandria, VA.

Marques-Neto, J.F., A. Lapa, and M. Kubota. 1988. Efeitos do Ageratum conyzoides Lineé no tratamento da artrose. Rev. Bras. Reumat. 28(4):34-37.

Ming, LC. (1999). Ageratum conyzoides: A tropical source of medicinal and agricultural products. In Perspectives on New Crops and New Uses. Janick J., Alexandria VA (eds.). ASHS Press; USA, pp. 469- 473.

Moura. ACA., Silva, ELF., Fraga, MCA. and Wanderley, AG. (2005). Anti-inflammatory and chronic toxicity study of the leaves of Ageratum conyzoides L. in rats. Phytomedicine. 12: 138142.

Okunade, AL. (2002). Review: Ageratum conyzoides L. (Asteraceae). Fitoterapia, 73: 1-16.

Oladejo, OW., Imosemi, IO., Osuagwu, FC., Oluwadara, OO., Aiku A., Adewoyin, O., Ekpo, OE., Oyedele, OO. and Akang, EEU. (2003). Enhancement of cutaneous wound healing by methanolic extracts of Ageratum conyzoides in the wistar rats. Afr. J. Biomed. Res., 6: 27- 31.

Oliveira, F., Akisue, M.K. and Garcia, L.O. (1993). Caracterização farmacognóstica da droga e do extrato fluído de mentrasto, Ageratum conyzoides L. Lecta 11(1):63-100.

Oliver, B. (1960). Medicinal plants in Nigeria. 1st Edition. Nigerian College of Arts and Science and Technology, Ibadan, pp. 17-41.

Owolabi, J.O., Omogbai, E.K.I., and Oduru, E.E. (2007). Antidiarrhoeal evaluation of the aqueous leaves extract of Custus lucanusianus-Family Costacea. J. Applied Sciences Research, 2007, 3(12), 2052-2055

Rajeev Kumar, Ram Jee Sharma, Khemraj Bairwa, Ram Kumar Roy, Arun Kumar. Pharmacological review on natural antidiarrhoel agents. Der Pharma Chemica, 2010, 2(2): 66-93.

Rosangkima, G., Prasad, SB. (2004). Antitumour activity of some plants from Meghalaya and Mizoram against murine ascites Dalton's lymphoma. Indian J Exp Biol. 42(10): 981-8.

Sampson, JH., Phillipson, JD., Bowery, NG. (2000). Ethnomedicinally selected plants as sources of potential analgesic compounds; Indication of in vitro biological activity in receptor binding assays. Phytother Res.14(1): 24-9. 
Sarangi Rashmi Ranjan, Mishra Uma Shankar, Panda Susanta Kumar, Behera Saiprasanna evaluation of antidiarrhoeal activity of Sida rtiombifolia linn. Root International research journal of pharmacy. 2. (9), 157-160.

Silva, MJ., Capaz, FR., Vale, MR. (2000) Effects of the water soluble fraction from leaves of Ageratum conyzoides on smooth muscle. Phytother Res 14(2): 130-2.

Venkatesan, N., Vadivu, T. and Sathiya, N. (2005). Anti-diarrhoeal potential of Asparagus racemosus wild root extracts in laboratory animals. J Pharm Sci;8:39-45.

Victoria Chinwe Ukwe, Ebele Agnes Epueke, Obinna Ikechukwu Ekwunife, Theophine Chinwuba Okoye, Godwin Christian Akudor, and Chukwuemeka Micheal Ubaka. (2010). Antimalarial activity of aqueous extract and fractions of leaves of Ageratum conyzoides in mice infected with Plasmodium berghei. International Journal of Pharmaceutical Sciences, Vol.2 (1) 33-38.
Victoria, CG., Bryce, J., Fontaine, O. and Monasch, R. (2000). Reducing deaths from diarrhoea through oral rehydrationtherapy. Bulletin of World Health Organization.78: 1246 -1255.

World Health Organization. (1990).Programme for Control of Diarrhoeal Diseases. Eighth Programme Report 1990-91 (WHO/CDD/92.38).

World Health Organization. (2013). Diarrhoeal Diseases. (Fact sheet $\mathrm{N}^{\circ} 330$ ).

Yamamoto, LA., Soldera, JC. and Emin, JA. (1991). Pharmacological screening of Ageratum conyzoides (Mentrasto) Mem Inst Oswaldo cruz 86 Suppl 2: 145-7 cit PMID 1841989. 